\title{
The effect of appendix diameter on perforation in acute appendicitis cases
}

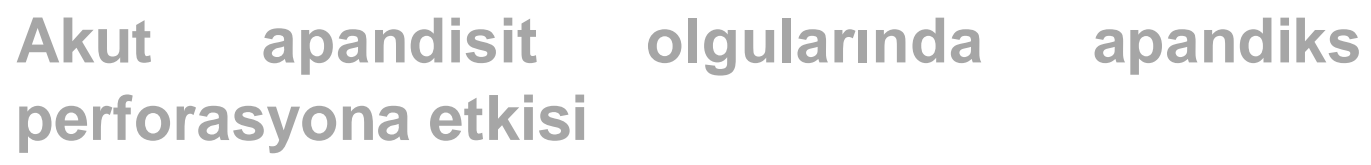

çapının

\author{
Katipoglu Burak ${ }^{1}$, Aygun Ali², Cinar Hamza ${ }^{3}$
}

${ }^{1}$ Department of Emergency Medicine, Faculty of Medicine, Ufuk University, Ankara, Turkey

${ }^{2}$ Department of Emergency Medicine, Faculty of Medicine, Ordu University, Ordu, Turkey

${ }^{3}$ Department of General Surgery, Faculty of Medicine, Ordu University, Ordu, Turkey

Corresponding author: Burak Katipoğlu, MD, Department of Emergency Medicine, Faculty of Medicine, Ufuk University, Ankara, Turkey

E-mail: burak44katipoglu@gmail.com

Received/Accepted: May 20, 2019 /June 24, 2019

Conflict of interest: There is not a conflict of interest.

\section{SUMMARY}

Objective: The aim of the study is to examine the association between appendix diameter and perforation and to show the significance of appendix diameter in acute appendicitis cases.

Method: The data of 286 cases who were older than 18 years of age and who were operated in a tertiary hospital between 2017 and 2018 with a diagnosis of acute appendicitis were examined retrospectively. The patients' ages, genders, pathology results, appendix diameter at abdominal tomography, white blood cell (WBC), and C-reactive protein (CRP) values were analyzed. The patients were grouped in three as perforated, non-perforated, and negative appendectomy group.

Results: Of the 286 patients operated with a diagnosis of AA, $166(58 \%)$ were male, while $122(42 \%)$ were the female and the average age of the patients was $37 \pm 16.79$ years. The non-perforated group consisted of 194 patients, while the perforated group consisted of 56 patients, and negative appendectomy group consisted of 36 patients. Average appendix diameter of the patients was $8.84 \pm 3.29 \mathrm{~mm}$, while the average $\mathrm{WBC}$ value was $13071 \pm 3726 / \mathrm{mm}^{3}$ and average CRP value was $3.44 \pm 5.15 \mathrm{mg} / \mathrm{L}$. When the patients' appendix diameters and CRP values were compared, a statistically significant difference was found between the groups $(\mathrm{p}<0.001)$. The average value of white blood cell was the lowest in negative appendectomy group, while it was the highest in the perforated group. There was a statistically significant difference between negative appendectomy group and the other two groups in terms of white blood cell $(\mathrm{p}<0.001)$. There was a positive correlation between the groups in terms of appendix diameter, white blood cell, and CRP $(\mathrm{p}<0.001)$.

Conclusions: Appendix diameter is important in the diagnosis of acute appendicitis and detection of perforated appendicitis. Appendix diameter is correlated with white blood cell and CRP.

Keywords: Acute appendicitis, perforation, appendix diameter, abdominal pain

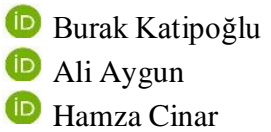

ORCID IDs of the authors: B.K. 0000-0002-4347-6258 A.A. 0000-0002-5190-1445 H.C. 0000-0003-1748-1392 
Amaç: Akut apandisit olgularında apandiks çapının önemini ve perforasyonla olan ilişkisini irdeleyip ortaya koymak amaçland1

Yöntem: Ordu Üniversitesi Tıp Fakültesi Eğitim Araştırma Hastanesinde akut apandisit tanısıyla 2017-2018 yılları arasında ameliyat edilen 18 yaşından büyük 286 hastanın verileri geriye dönük olarak incelendi. Hastaların yaş, cinsiyet, patoloji sonuçları, batın tomografisindeki apandiks çapı, kan beyaz küre ve C-reaktif protein (CRP) değerleri analiz edildi. Hastalar perfore, non perfore ve negatif apandektomi grubu olarak 3'e ayrildı.

Bulgular: AA tanısı ile opere edilen 286 hastanın166 (\%58)'sı erkek $122(\% 42)$ 'si kadın olup yas ortalamaları $37 \pm 16.79$ yll idi. Non perfore grup 194, perfore grup 56 ve negatif apandektomi grubu ise 36 hastadan olușmaktaydı. Hastaların apendiks çapı ortalaması $8.84 \pm 3.29 \mathrm{~mm}$, kan beyaz küre değeri ortalaması $13071 \pm 3726 / \mathrm{mm}^{3}$ ve CRP değeri ortalaması $3.44 \pm 5.15 \mathrm{mg} / \mathrm{L}$ idi. Hasta gruplarının apendiks çapları ve CRP değerleri karşılaştıııldı̆̆ında gruplar arası istatistiksel olarak anlamlı bir fark vardı $(\mathrm{p}<0.001)$. Beyaz kürenin ortalama değeri negatif apandektomi grubunda en düșük perfore grubunda ise en yüksekti. Negatif apandektomi grubu ile diğer iki grup arasında beyaz küre açısından istatistiksel olarak anlamlı bir fark vardı $(\mathrm{p}<0.001)$. Gruplar arasında apandiks çapı, beyaz küre ve CRP arasında pozitif korelasyon vard1 $(\mathrm{p}<0.001)$.

Sonuç: Akut apandisit tanısında ve perfore apandisitlerin tespitinde apandiks çapı önemlidir. Apandiks çapı, beyaz küre ve CRP ile birlikte koreledir.

Anahtar sözcükler: Akut apandisit, apandiks çapı, karın ağrısı, perforasyon

\section{INTRODUCTION}

Acute appendicitis (AA) is the leading acute abdominal cause seen in patients who refer to emergency service with abdominal pain. With a delayed diagnosis of AA, appendix perforation and as a result of this, peritonitis, intraabdominal abscess, sepsis, and ileus can develop in patients. ${ }^{1}$ In AA patients; perforation diagnosis is frequently made with intraoperative observation or postoperative histopathological examination.

For this reason, it is of critical importance for perforation diagnosis to be made timely and correctly in AA patients to prevent complications that will occur as a result of this. ${ }^{2}$ Anamnesis, physical examination, increase in blood inflammatory parameters, radiological imaging and clinical experience have a significant place in the diagnosis. There are studies which show that inflammatory blood parameters, which are indicators of acute inflammation such as white blood cell count, C-reactive protein (CRP), procalcitonin, pentraxin-3 are associated with AA. ${ }^{3,4}$ Although there are disputes about which radiological imaging method to be used in the diagnosis of AA, it has been reported by a large number of studies that abdominal computed tomography is more reliable in the diagnosis of AA. ${ }^{5}$

In the present study, we aim to assess the significance of appendix diameter in AA cases and to examine its association with perforation and blood inflammatory parameters.

\section{MATERIAL AND METHODS}

The study was conducted after the approval of Ordu University Faculty of Medicine Clinical Researches Ethics Board (decision No.2019/89) was taken. In the study, the data of patients older than 18 who referred to the emergency service of a tertiary hospital with a complaint of abdominal service and who were hospitalized with a prediagnosis of acute appendicitis between the dates 01.01.2017 and 31.12.2018 were examined retrospectively. All of the patients who had an abdominal computed tomography (CT) for AA diagnosis were included in the study. The patients who did not have CT, whose appendix diameters were not measured in $\mathrm{CT}$ and whose data were missing were not included in the study. The patients who were hospitalized with the prediagnosis of AA but who were not operated were excluded. Postoperative histopathological results of the patients included in the study were examined. According to histopathological results, the patients were grouped in three as perforated AA, non-perforated AA, and those whose postoperative surgical results were not compatible with AA (negative appendectomy). The patients' age, gender, WBC, and CRP values were recorded. Appendix diameters were recorded in $\mathrm{mm}$. Perforated appendicitis, non-perforated appendicitis, and negative appendectomy patients' appendix diameters in abdominal CT were compared.

\section{Statistical Analysis}

A statistical package program was used for data analysis. Descriptive statistics of the assessment results were given in numbers and percentage for categorical variables and as average, standard deviation (SD), minimum (min), and maximum $(\max )$ for numerical variables. Kolmogorov Smirnov test was used for normality distribution. In the comparison of groups, ANOVA test was used to compare the groups in parameters that 
were normally distributed, and the Kruskal-Wallis test was used to compare the groups in parameters that were not normally distributed. When the ANOVA test was found to be significant, Tukey test was used in comparisons of two if the groups were homogeneous, while Tamhane's test was used if they weren't. When the Kruskal-Wallis test was found to be significant, Bonferroni corrected Mann Whitney U test was used for comparisons of two. Correlation coefficients and statistical significance of the variables were calculated with the Pearson test for the variables which were normally distributed, and with Spearman test for the variables which were not normally distributed. Statistical significance level was accepted as $\mathrm{p}<0.05$.

\section{RESULTS}

In the study, the data of 296 patients who had a pre-diagnosis of AA in the emergency service between the dates 01.01.2017 and 31.12.2018 were analyzed. Since ten patients were discharged as a result of clinical follow-up without being operated, they were excluded from the study. Two hundred eighty-six patients were operated with a diagnosis of AA. 166 (58\%) of the patients were male, while $122(42 \%)$ were female. The average age of the patients was $37 \pm 16.79$, with min: 18 , max:93. Average appendix diameter of the patients was $8.84 \pm 3.29 \mathrm{~mm}$, average $\mathrm{WBC}$ value was $13071 \pm 3726 / \mathrm{mm}^{3}$, and average CRP value was $3.44 \pm 5.15 \mathrm{mg} / \mathrm{L}$. Table 1 shows the age, gender, and clinical data distribution of the patient groups.

Statistically, a significant difference was found in appendix diameter comparison of patient groups $(\mathrm{p}<0.001)$. No statistically significant difference was found between WBC values of the nonperforated AA patient group and perforated AA patient group ( $\mathrm{p}=0.088)$. Statistically, a significant difference was found in the comparison of WBC values of negative appendectomy patient group with the other patient groups $(\mathrm{p}<0.001)$. Statistically, a significant difference was found in CRP values comparison of patient groups $(\mathrm{p}<0.001)$ (Table 2). Average appendix diameter of 158 non-perforated AA patients with a WBC value of $\geq 10000 / \mathrm{mm}^{3}$ was $8.71 \pm 1.71 \mathrm{~mm}$, while the average appendix diameter of 51 perforated AA patients with a WBC value of $\geq 10000 / \mathrm{mm}^{3}$ was $12.73 \pm 2.73 \mathrm{~mm}$. Average appendix diameter of 36 non-perforated AA patients with a WBC value of $<10000 / \mathrm{mm}^{3}$ was $7.96 \pm 1.06 \mathrm{~mm}$, while the average appendix diameter of 5 perforated AA patients with a WBC value of $<10000 / \mathrm{mm}^{3}$ was $12.60 \pm 1.51 \mathrm{~mm}$. When the correlation between appendix diameter and WBC and CRP was examined, low ( $\mathrm{r}$ values 0.28 and 0.23 , respectively) statistically significant positive correlation was found ( $\mathrm{p}<0.001$ for both values).

Table 1: Age, gender, WBC, CRP and appendix diameter values of patient groups

\begin{tabular}{lccc}
\hline & $\begin{array}{c}\text { Non-perforated AA } \\
(\mathbf{n = 1 9 4})\end{array}$ & $\begin{array}{c}\text { Perforated AA } \\
(\mathbf{n = 5 6})\end{array}$ & $\begin{array}{c}\text { Negative } \\
\text { appendectomy } \\
(\mathbf{n}=\mathbf{3 6})\end{array}$ \\
\hline Sex, Male (\%) & $120(61.9)$ & $34(60.7)$ & $12(33.3)$ \\
Female (\%) & $74(38.1)$ & $22(39.3)$ & $24(66.7)$ \\
\hline Age, mean \pm SD (min-max) & $35.65 \pm 15.16$ & $42.96 \pm 20.26$ & $35.03 \pm 17.69$ \\
& $(18-87)$ & $(18-93)$ & $(18-82)$ \\
\hline WBC $\left(\right.$ cells/mm $\left.{ }^{3}\right)$ & $13169 \pm 3585$ & $14322 \pm 3788$ & $10598 \pm 3287$ \\
\hline CRP $(\mathrm{mg} / \mathrm{L})$ & $3.23 \pm 4.91$ & $5.21 \pm 6.33$ & $1.79 \pm 3.39$ \\
\hline Appendix diameter $(\mathrm{mm})$ & $8.58 \pm 1.63$ & $12.72 \pm 2.64$ & $4.21 \pm 3.99$ \\
\hline
\end{tabular}


Table 2: Comparison of WBC, CRP and appendix diameter averages of patient groups

\begin{tabular}{|c|c|c|c|c|}
\hline & $\begin{array}{c}\text { Non-perforated } \\
\begin{array}{c}\mathrm{AA}^{\mathrm{a}} \\
\mathrm{n}=194 \\
(\operatorname{mean} \pm \mathrm{SD})\end{array}\end{array}$ & $\begin{array}{c}\text { Perforated } \mathrm{AA}^{\mathrm{b}} \\
\qquad \mathrm{n}=56 \\
(\operatorname{mean} \pm \mathrm{SD})\end{array}$ & $\begin{array}{c}\text { Negative } \\
\text { Appendectomy }^{\mathrm{c}} \\
\mathrm{n}=\mathbf{3 6}(\text { mean } \pm \text { SD })\end{array}$ & p Value \\
\hline $\begin{array}{l}\text { WBC } \\
\left(\text { cells/mm } / \mathbf{m m}^{3}\right)\end{array}$ & $13169 \pm 3585$ & $14322 \pm 3788$ & $10598 \pm 3287$ & $\begin{array}{c}\mathrm{p}<0.001^{\alpha} \\
\mathrm{p}^{\mathrm{a}, \mathrm{b}}=0.088^{\gamma}, \mathrm{p}^{\mathrm{a}, \mathrm{c}}<0.001^{\gamma}, \\
\mathrm{p}^{\mathrm{b}, \mathrm{c}}<0.001^{\gamma}\end{array}$ \\
\hline $\begin{array}{l}\text { CRP } \\
(\mathrm{mg} / \mathrm{L})\end{array}$ & $3.23 \pm 4.91$ & $5.21 \pm 6.33$ & $1.79 \pm 3.39$ & $\begin{array}{c}\mathrm{p}<0.001^{\beta} \\
\mathrm{p}^{\mathrm{a}, \mathrm{b}}=0.021^{\delta}, \mathrm{p}^{\mathrm{a}, \mathrm{c}}=0.004^{\delta}, \\
\mathrm{p}^{\mathrm{b}, \mathrm{c}}<0.001^{\delta}\end{array}$ \\
\hline $\begin{array}{l}\text { Appendix } \\
\text { diameter } \\
(\mathrm{mm})\end{array}$ & $8.58 \pm 1.63$ & $12.72 \pm 2.64$ & $4.21 \pm 3.99$ & $\begin{array}{c}\mathrm{p}<0.001^{\beta} \\
\mathrm{p}^{\mathrm{a}, \mathrm{b}}<0.001^{\delta}, \mathrm{p}^{\mathrm{a}, \mathrm{c}}<0.001^{\delta}, \\
\mathrm{p}^{\mathrm{b}, \mathrm{c}}<0.001^{\delta}\end{array}$ \\
\hline
\end{tabular}

In ROC analysis conducted to measure the diagnostic value of appendix diameter in perforated appendicitis, the area under the curve was found as $0.91 \quad(\mathrm{p}<0.001,95 \%$ confidence interval 0.87-0.95), (Figure 1). When the cut off value of appendix diameter was taken as $9.25 \mathrm{~mm}$, its sensitivity for appendicitis diagnosis was found as $91 \%$, and its specificity was found as $79 \%$.

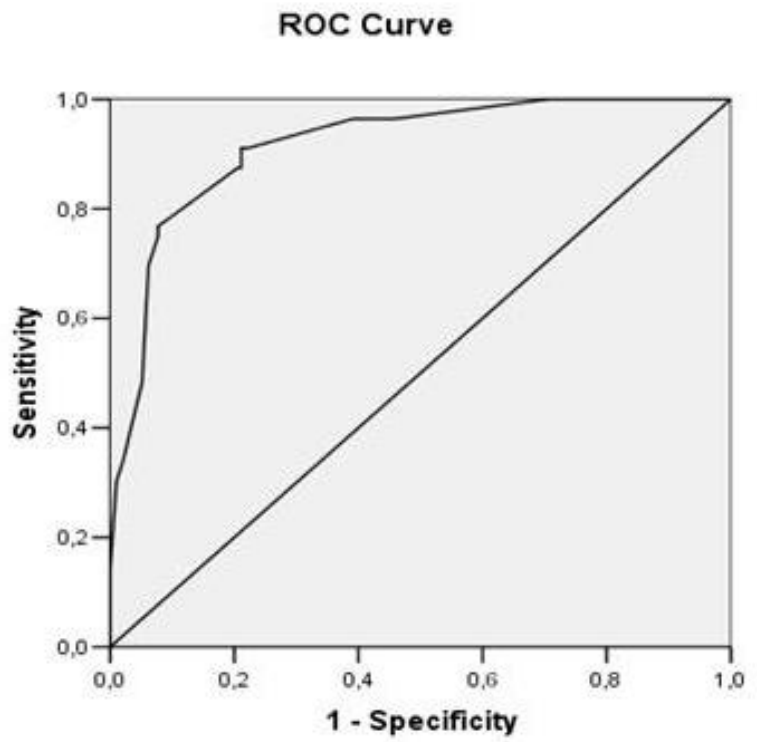

Figure 1: ROC analysis graph conducted to measure the diagnostic value of appendix diameter in perforated acute appendicitis patients.

\section{DISCUSSION}

Despite the advancements in the field of medicine, it is very difficult to make AA diagnosis even today. Delays in diagnosis and surgical intervention can cause AA perforation. In AA cases, one of the most important reasons for the increase in morbidity and mortality is developing perforation. ${ }^{2}$ At the same time, it can be seen in literature that still in $10-20 \%$ of the patients operated with a pre-diagnosis of AA, pathological diagnosis is not $\mathrm{AA}^{4,6,7}$ In the diagnosis of $\mathrm{AA}$, in which negative appendectomy is so high, imaging techniques such as abdominal ultrasonography, abdominal CT, and abdominal magnetic resonance (MR) are important. ${ }^{8}$ In the diagnosis of AA, CT has been reported to have a sensitivity of $90-100 \%$, a specificity of $91-99 \%$, a positive predictive value of $92-98 \%$ and a negative predictive value of $95-100 \%$. The use of CT has caused a decrease in negative appendectomy and perforated AA cases. ${ }^{9-11}$ In our study, when CT was taken as the diagnostic imaging method in AA cases, $19.6 \%$ of the 286 patients were found to be perforated $\mathrm{AA}$, while $12.6 \%$ were found to be negative appendectomy and these results were in parallel with the literature. In imaging techniques, one of the most important findings in making AA diagnosis is appendix diameter. The diameter of the normal appendix is $6 \mathrm{~mm}$ or less. ${ }^{12,13}$ In AA, when appendix diameter is over 6 $\mathrm{mm}$, sensitivity has been reported as $93 \%$, while 
specificity has been reported as $92 \% .{ }^{14}$ If the appendix diameter is $10 \mathrm{~mm}$ and over, the case can be accepted as AA. In a study by Webb et al., while all of the cases with an appendix diameter of $10 \mathrm{~mm}$ and over were found to be $\mathrm{AA}$, in Benjamin et al.'s study, while only 1 of the patients 187 patients with an appendix diameter of over $10 \mathrm{~mm}$ was normal, the other 1986 were found to be AA. ${ }^{13,15}$ Of the CT findings, the presence of extra lumen gas, abscess or phlegmon, extra luminal appendicolith and focal defect in appendix wall can be indicators of AA perforation. The rate of perforation increases as the appendix diameter increases. In a study by Bixby et al., while the average diameter was found as $15.1 \mathrm{~mm}$ in the perforated appendix, it was found as $11 \mathrm{~mm}$ in the non-perforated appendix. ${ }^{15}$ The results of our study are in parallel with the literature, and a significant association was found between diameter increase and perforation $(\mathrm{p}<0.001)$. While the average appendix diameter was $8.58 \pm 1.63 \mathrm{~mm}$ in our nonperforated cases, the average diameter was found as $12.72 \pm 2.64 \mathrm{~mm}$ in perforated cases. When the cut-off values of appendix diameter were taken as $9.25 \mathrm{~mm}$, sensitivity was found as $91 \%$, and specificity was found as $79 \%$ for perforated appendicitis diagnosis. White blood cell and CRP are very valuable in the diagnosis of AA. When the literature is reviewed, sensitivity and specificity values of both in AA diagnosis are around $90 \% .^{17,18}$ In perforated AA cases, white blood cell and CRP values are higher when compared with non-perforated AA. ${ }^{19}$ In AA, the intensity of inflammatory response which occurs as a result of the spread of inflammation to the peritoneal cavity with perforation increases. In our study, both white blood cell and CRP values were found to be higher in perforated patients when compared with non-perforated patients. In our cases, white blood cell and CRP values were found to increase directly proportionally to appendix diameter. This brings to mind that perforated AA should be suspected in patients with high appendix diameter and WBC and CRP values. In patients who refer to the emergency service with right lower quadrant pain, anamnesis, physical examination, laboratory findings, and increase in appendix diameter in $\mathrm{CT}$ are important in AA diagnosis.

\section{CONCLUSION}

In AA diagnosis, appendix diameter is important. In perforated AA patients, white blood cell and WBC parameters increase directly proportionally to appendix diameter.
Acknowledgments: We thank radiologist Dr. Serdar Altay for their help in this study.

Author Contributions: Concept- B.K., A.A.; Design- B.K., A.A; Supervision- B.K., A.A, H.C.; Resources- A.A, H.C.; Data Collection and/or Processing- A.A, H.C.; Analysis and/or Interpretation- A.A, B.K.; Literature Search- A.A, B.K.; Writing Manuscript- B.K., A.A.; Critical Review- B.K., A.A, H.C.

\section{REFERENCES}

1. Sarac M, Bakal Ü, Tartar T, Kazez A. The Role of the Doctors in Perforated Appendicitis. Firat Med J 2014;19:126-29.

2. Akay S., Akay H, Vardar E, Erkul Z. Comparison of Eosinophil Values with Other Biomarkers in Predicting Perforation of Acute Appendicitis. Eurasian J Emerg Med 2017; 16: 8-11.

3. Aygun A, Katipoglu B, Imamoglu M, Demir S, Yadigaroglu M, Tatli O, et al. Diagnostic Value of Plasma Pentraxin-3 in Acute Appendicitis. J Invest Surg. 2017;11:1-6.

4. Mengucuk ME, Ayten R, Bulbuller N, Godekmerdan A, Basbug M, Mungan I. The place of serum C-reactive protein, procalcitonin, and neopterin in the diagnosis of acute appendicitis. Firat Med. J. 2010;15(1):40-43.

5. Yildirim O, Solak C, Koçer B, Unal B, Karabeyoglu M, Bozkurt B, et al. The role of serum inflammatory markers in acute appendicitis and their success in preventing negative laparotomy. J Invest Surg. 2006;19:345-352.

6. Gokce AH, Aren A, Gokce FS, Dursun N, Barut AY. Reliability of ultrasonography for diagnosing acute appendicitis. Ulus Travma Acil Cerrahi Derg. 2011;17(1):19-22

7. Binnebosel M, Otto J, Stumpf M, Mahnken AH, Gassler N, Schumpelick V, et al. Acute appendicitis. Modern diagnostics-surgical ultrasound. Chirurg. 2009 Jul;80(7):579-87.

8. Birnbaum, BA, and. Wilson SR. Appendicitis at the Millennium. Radiology. 2000; 215:337348.

9. Jain RK, Jain M, Rajak CL, Mukherjee S, Bhattacharyya PP, Shah MR. Imaging In Acute Appendicitis: A Review. Ind J Radiol Imag 2006 16:4:523-32

10. Raptopoulos V, Katsou G, Rosen MP, Siewert B, Goldberg SN, Kruskal JB. Acute Appendicitis: Effect of Increased Use of CT on Selecting Patients Earlier. Radiology 2003; 226:521-526. 
11. Kaiser S, Frenckner B, Jorulf HK. Suspected Appendicitis in Children: US and CT- A Prospective Randomized Study. Radiology 2002; 223:633-638.

12. Baldisserotto M, Marchiori E. Accuracy of Noncompressive sonography of children with appendicitis according to the potential positions of the Appendix. AJR 2000; 175:1387-1392

13. Benjaminov O, Atri $\mathrm{M}$, Hamilton $\mathrm{P}$, and Rappaport D. Frequency of Visualization and Thickness of Normal Appendix at Nonenhanced Helical CT. Radiology 2002; 225:400-406.

14. Arévalo O, Moreno M, Ulloa L. Acute appendicitis: imaging findings and current approach to diagnostic images. Rev Colomb Radiol. 2014; 25(1): 3877-88

15. Webb EM, Wang ZJ, Coakley FV, Poder L, Westphalen AC, Yeh BM .The equivocal appendix at CT: Prevalence in a control population. Emerg Radiol. 2010;17:57-61.

16. Bixby SD, Lucey BC, Soto JA, Theysohn JM, Ozonoff A, Varghese JC. Perforated versus nonperforated acute appendicitis: Accuracy of multidetector CT detection. Radiology. 2006;241:780-786.
17. Yu CW, Juan LI, Wu MH, Shen CJ, Wu JY, Lee CC. Systematic review and meta-analysis of the diagnostic accuracy of procalcitonin, Creactive protein and white blood cell count for suspected acute appendicitis. $\mathrm{Br} \mathrm{J}$ Surg. 2013;100(3):322-9.

18. Shafi SM, Afsheen M, Reshi FA. Total Leucocyte Count, C-reactive protein and neutrophil count: Diagnostic aid in acute appendicitis. Saudi J Gastroenterol. 2009;15(2):117-20.

19. McGowan DR, Sims HM, Zia K, Uheba M, Shaikh IA. The value of biochemical markers in predicting a perforation in acute appendicitis. ANZ journal of surgery 2013:83(1-2); 79-83. 